\title{
ACCESSORY SPLEEN - A CASE REPORT WITH A BRIEF REVIEW
}

Keisam Anupama Devi', Laitonjam Chinglensana²

\section{HOW TO CITE THIS ARTICLE:}

Keisam Anupama Devi, Laitonjam Chinglensana. "Accessory Spleen - A Case Report with a Brief Review". Journal of Evolution of Medical and Dental Sciences 2014; Vol. 3, Issue 08, February 24; Page: 1859-1863, DOI: $10.14260 /$ jemds/2014/2070

ABSTRACT: Accessory spleen (AS) is a congenital ectopic splenic tissue arising during embryologic period of development, most remaining asymptomatic and discovered incidentally. Being present near the splenic hilum usually, it may occasionally be embedded partly or wholly in the tail of the pancreas, sometimes becoming symptomatic and even mimicking tumor. We report a case of an accessory spleen discovered during cadaveric dissection of a middle-aged man in the Department of Anatomy, RIMS, Imphal. Awareness of the possible presence of AS is important during splenectomy for conditions such as immune thrombocytopenic purpura as failure to remove the AS may result in the failure of the condition to resolve. Additionally, during medical imaging, AS may be confused for enlarged lymph nodes or neoplastic growths. The presented case report might remind us the sort of such congenital anomalies during clinical evaluations like splenomegaly, splenic trauma, lymphadenopathies and intra-abdominal mass and subsequent operative strategies.

KEY MESSAGE: A routine search for AS intraoperatively along with preoperative radiological scan is recommended to achieve the highest detection rates and to prevent disease recurrence, especially for autoimmune hematological disorders.

INTRODUCTION: The spleen consists of a large encapsulated mass of vascular and lymphoid tissue situated in the upper left quadrant of the abdominal cavity between the fundus of the stomach and the diaphragm. The spleen can display various developmental anomalies, including complete agenesis, multiple spleens or polysplenia, isolated small additional splenunculi and persistent lobulation ${ }^{1}$. Accessory spleens may be formed during embryonic development as ectopic or separated splenic tissue along the path from where the spleen forms at the midline to the spleen's final location on the left side of the abdomen.1,2

Accessory spleen, found in $10 \%-30 \%$ of patients at autopsy, is due to the fusion failure of the splenic anlage, which is located in the dorsal mesogastrium..$^{3-5}$ The splenic hilus is the most common site of an accessory spleen followed by pancreatic tail. Because an accessory spleen does not usually require treatment, accurate preoperative diagnosis is important.

CASE REPORT: A middle-aged Indian male cadaver allocated for academic anatomical dissection in Department of Anatomy, RIMS, Imphal, was incidentally discovered to possess an accessory spleen during routine abdominal dissection. There was no other discernible anatomical anomaly either in the abdomen or elsewhere. This is the first reported case observed in our department, representing a frequency of 3.33\% (1/30 cadavers) during the period 1980-2012.

Size and position of the AS: It was located in the left hypochondrium infero-medial to the primary spleen at the level of lower third of first lumbar vertebra (Fig. 1). The primary spleen measures $18 \mathrm{cms}$ in length, $14 \mathrm{cms}$ in breadth and $4 \mathrm{cms}$ in thickness, weighing $290 \mathrm{gm}$ whereas the ovoid accessory spleen measures $5 \mathrm{cms}$ in length, $3.5 \mathrm{cms}$ in breadth and $3 \mathrm{cms}$ in thickness and 
weighs $68 \mathrm{gm}$ (Fig. 2). This dimension is considered large as the usual size reported for AS is about 2 cms or smaller typically. The separate pedicle of the AS is connected to the hilum (Fig. 3), and runs parallel to the primary splenic pedicle for about $5 \mathrm{cms}$ before subsequently joining it in the gastrosplenic ligament.

Vascular system: The arterial supply of the AS through the separate pedicle was provided by a branch of the splenic artery that originates from the inferior aspect $4 \mathrm{cms}$ before it penetrates the hilum of the primary spleen. The venous drainage also corresponds to the artery in the pedicle.

DISCUSSION: Splenunculi or accessory spleen is a congenital condition seen in 10-44\% of necropsies. ${ }^{6}$ An accessory spleen arises from the side of the dorsal mesogastrium during embryological period of development as a result of imperfect fusion of separate splenic masses. Most often there is one accessory spleen (85\%) sometimes two (14\%) and rarely three or more $(1 \%)$. Their size is not larger than $2 \mathrm{~cm}$ in diameter. The most common location is hilum of the spleen in gastrosplenic ligament (50\%), but may be found behind the tail of pancreas $(30 \%)$ or rarely within greater omentum of the stomach, mesentery of the small intestine, mesocolon, pancreas, ${ }^{7}$ kidney ${ }^{8}$ and pelvis as an adnexal mass. ${ }^{9}$.Most of the splenunculi are asymptomatic and are discovered incidentally by abdominal ultrasound, CT scan or laparotomy during the investigation of another problem. In a few cases they become symptomatic causing abdominal pain due to torsion and infarction 10 . Accessory spleen needs to be distinguished from splenosis which is an acquired condition associated with splenic trauma or surgery having incidence of $67 \%$ in these patients ${ }^{11}$. Splenosis presents as numerous nodules (as many as 400) in any intraperitoneal or extraperitoneal location. Splenosis nodules receive their blood supply from newly formed arteries penetrating the capsule. Histologically it is possible to differentiate splenunculi from splenosis. Splenunculi have well-formed capsule, hilum, trabeculae, white pulp with Malphigian follicles having central arteriole and red pulp whereas splenosis nodule are surrounded by capsule but Malphigian follicles with a central arteriole are not formed. Splenunculi are important in hematological disorders for which splenectomy is the treatment of choice. If surgeon is not able to locate or remove them at the time of splenectomy, they will undergo hyperplasia and cause recurrence of the disease. Accessory spleens resemble normal spleen in structure and in immunologic functions. So in splenectomy for non-hematologic causes accessory spleens should be preserved to prevent infection and sepsis after splenectomy. In addition splenunculi can mimic tumors of the kidney, pancreas and pelvis. Thus it is important to identify splenunculi either by CT scan or by $99 \mathrm{~m}$ Tc heat-denatured red blood cell scan and confirmed by histopathologic examination to avoid misdiagnosis.

Many authors reported an incidence rate between 10 and $30 \%$ especially in patients undergoing splenectomy for hematologic diseases. ${ }^{4,12,13}$ Park et al ${ }^{14}$ reported an incidence rate of $15.0 \%$ for AS in patients undergoing laparoscopic splenectomy for different hematologic diseases. Mortele' et al ${ }^{15}$ used contrast enhanced CT imaging and they reported that a 2-mm size accessory spleen can be determined by contrast enhanced CT. There is a lack of prospective consecutive autopsy series studies for determining the incidence of AS in different populations in the literature. The reported frequencies for one, two and three AS have been reported as 79-86\%, 10.5-14\%, and

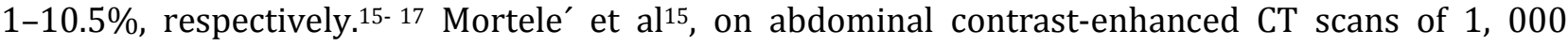
consecutive patients reported that $156(15.6 \%)$ had at least one accessory spleen, and 21 of these patients (13\%) had more than one accessory spleen (two or three), resulting in a total of 180 AS. 
Awareness of the presence of an accessory spleen is important in a patient evaluated by CT prior to splenectomy, as failure to remove it may result in persistence of the condition that indicated the need for splenectomy.2,18 An accessory spleen may be of clinical importance as a source of "preservable" splenic tissue in cases of a ruptured primary spleen. Additionally, during medical imaging, AS may be confused for enlarged lymph nodes or neoplastic growths. An AS is an incidental finding of no clinical significance in most patients. AS are generally determined during radiological investigations or during open or laparoscopic surgeries. ${ }^{19}$ AS are usually asymptomatic, but they are rarely reported to present clinically as an abdominal mass related to complications such as torsion, spontaneous rupture, hemorrhage, and cyst formation. Torsion and ischemia of AS can lead to gangrene, abscess, peritonitis, and can present as an acute abdomen, as seen in torsion of the main spleen. ${ }^{16,19}$

CONCLUSION: Although an accessory spleen usually appears as an isolated asymptomatic abnormality, it may have clinical significance in some situations. When an accessory spleen is located in the pancreas, it may mimic an islet cell tumor or a neoplasm.6-8 Because an accessory spleen does not usually require treatment, accurate preoperative diagnosis is important. In addition to studies on radiological scans and laparoscopic or open surgery series, autopsy series will be useful for determining the incidences and the other features of AS in different populations.

\section{REFERENCES:}

1. Standring SM. (ed.). 2005. Gray's Anatomy. 39th Ed. New York: Churchill Livingstone. p 1239, 1267.

2. Moore KL, Persaud TVN. The digestive system. In: Moore KL, Persaud TVN, editors. The Developing Human, Clinically Oriented Embryology. 5th ed. Philadelphia PA: WB Saunders 1993. p 245-248.

3. Freeman JL, Jafri SZ, Roberts JL, Mezwa DG, Shirkhoda A. CT of congenital and acquired abnormalities of the spleen. Radiographics 1993; 13: 597-610.

4. Dodds WJ, Taylor AJ, Erickson SJ, Stewart ET, Lawson TL. Radiologic imaging of splenic anomalies. AJR Am J Roentgenol 1990; 155: 805-810.

5. Chin S, Isomoto H, Mizuta Y, Wen CY, Shikuwa S, Kohno S. Enlarged accessory spleen presenting stomach submucosal tumor. World J Gastroenterol 2007; 13: 1752-1754.

6. Al Ahmadi, M., Brundage, S., Brody, F., Jacobs, L. and Sakier. Splenosis of the mesoappendix, A case report and review of literature. Journal of Royal College of Surgery Edinburgh 1998; 43: 200-202.

7. Hayward, I., Mindelzun, R.E. and Jeffrey, R.B. Intrapancreatic accessory spleen mimicking pancreatic mass on CT scan. Journal of Computerized Assisted Tomography 1992; 16: 984-985.

8. Servadio, Y., Leibovitch, I., Aprer, S., Mor, Y. and Goldwasser, B. Symptomatic heterotopic splenic tissue inleft renal fossa. European urology. 1994; 25: 174-76.

9. Azar, G.B., Awwad, J. T. and Muffarrij, I. K. Accessory spleen presenting as adnexal mass. Acta Obstetrica Gynecologica Scandnevica 1993; 72 587-588.

10. Raichuk, I.E., Chesakov, S. A., Niirchenko, I.y., Gerich, F. N., Kukuriku, E. V. and Bukree, V. M. Torsion of accessory spleen Klin Khir. 1994; 10: 64. 
11. Fleming, C. R. Dickson, E.R. and Harrison, E.G. Splenosis; autotransplantation of splenic tissue. Am J Med 1976; 61: 414-419.

12. Halpert B, Gyorkey F. Lesions observed in accessory spleens of 311 patients. Am J Clin Pathol 1959; 32: 165-168.

13. Glasgow RE, Yee LF, Mulvihill SJ. Laparoscopic splenectomy. The emerging standard. Surg Endosc 1997; 11:108-112.

14. Park A, Marcaccio M, Sternbach M, Witzke D, Fitzgerald P. Laparoscopic vs. open splenectomy. Arch Surg 1999; 134:1263-1269.

15. Mortele' KJ, Mortele' B, Silverman SG. CT features of the accessory spleen. AJR Am J Roentgenol 2004; 183:1653-1657.

16. Mendi R, Abramson LP, Pillai SB, Rigsby CK. Evolution of the CT imaging findings of accessory spleen infarction. Pediatr Radiol 2006; 36: 1319-1322.

17. Ungo"r B, Malas MA, Sulak O, Albay S. Development of spleen during the fetal period. Surg Radiol Anat 2007; 29: 543-550.

18. Gayer G, Zissin R, Apter S, Atar E, Portnoy O, Itzchak Y. CT findings in congenital anomalies of the spleen. Br J Radiol 2001; 74: 767-772.

19. Valls C, Mones L, Guma A, Lopez-Calonge E. Torsion of a wandering accessory spleen: CT findings. Abdom Imaging 1998; 23: 194-195.

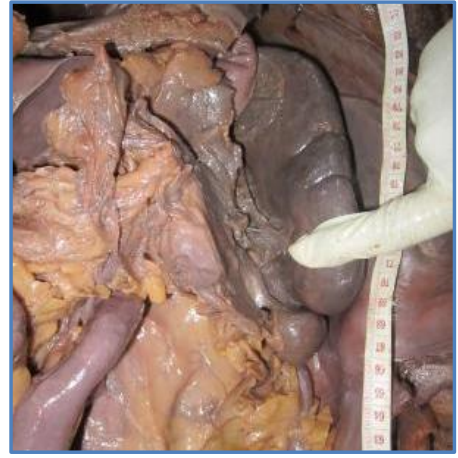

Fig. 1: Accessory spleen with pedicle position infero-medial to primary spleen

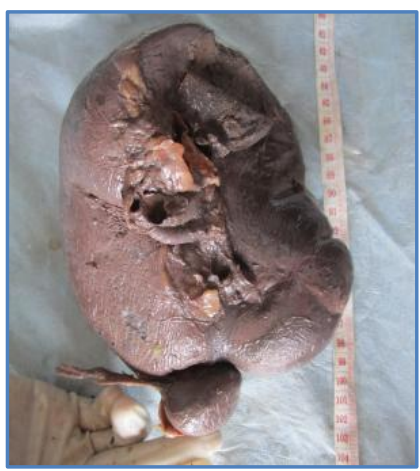

Fig. 2: Comparative size of accessory spleen to primary spleen

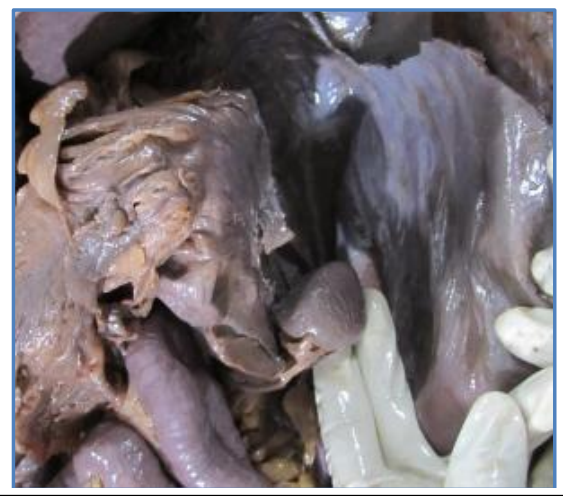

Fig. 3: The separate pedicle of the accessory spleen after removal of primary spleen 


\section{CASE REPORT}

\section{AUTHORS:}

1. Keisam Anupama Devi

2. Laitonjam Chinglensana

\section{PARTICULARS OF CONTRIBUTORS:}

1. Medical Officer, Manipur Health Services, ExPGT, Department of Anatomy, Regional Institute of Medical Sciences, Imphal, Manipur.

2. Registrar, Department of Surgery, Regional Institute of Medical Sciences, Imphal, Manipur.

\section{NAME ADDRESS EMAIL ID OF THE CORRESPONDING AUTHOR:}

Dr. Keisam Anupama Devi, Singjamei Thongam Leikai, Opposite SROY Club Leirak, Imphal West, PIN - 795008.

E-mail: anupama.keisam@gmail.com

Date of Submission: 25/01/2014.

Date of Peer Review: 27/01/2014.

Date of Acceptance: 10/02/2014.

Date of Publishing: 19/02/2014. 